\title{
Effect of the Cholesteryl Ester Transfer Protein Genotypes on Plasma Lipid and Lipoprotein Levels in Vietnamese Children
}

\author{
NGHIEM NGUYET THU, TA THI TUYET MAI, REIKO OHMORI, MASATOSHI KUROKI, \\ NGUYEN VAN CHUYEN, NGUYEN THI KIM HUNG, MASANOBU KAWAKAMI, AND KAZUO KONDO \\ Institute of Environmental Science and Human Life [N.N.T., K.K.], Ochanomizu University, Tokyo \\ 112-8610, Japan; Center for Child Nutrition [T.T.T.M., N.T.K.H.], Hochiminh, Vietnam; First Department \\ of Internal Medicine [R.O.], National Defense Medical College, Saitama 359-8513, Japan; Omiya \\ Medical Center [M.K., M.K.], Jichi Medical School, Saitama 329-8503, Japan; Department of Food and \\ Nutrition [N.V.C.], Japan Women's University, Tokyo 112-8681, Japan
}

\begin{abstract}
ABSTR
Cholesteryl ester transfer protein (CETP) is understood to
play a regulatory role in HDL cholesterol (HDLC) metabolism.
In this study, the effect of CETP genotypes on plasma lipid and
lipoprotein levels in 348 Vietnamese girls (aged 7-9) with
different nutritional conditions was analyzed. The two mutations,
intron $14 \mathrm{G}(+1)$-to-A (I14A) and Asp 442 to Gly within exon 15
(D442G), and the TaqIB polymorphism in the CETP gene were
identified by an Invader assay. The D442G mutation was present
with a frequency of 0.034, while the I14A mutation was absent.
HDLC levels were significantly higher in carriers of the D442G
mutation than in noncarriers, regardless of the nutritional status.
Low-density lipoprotein (LDL) cholesterol and triglyceride lev-
els were not significantly lower in carriers of D442G mutation.
\end{abstract}
HDLC levels in plasma may be altered by a variety of environmental factors including alcohol consumption, a low fat diet, obesity, smoking, and exercise (1). In the general population, about $50 \%$ of plasma HDLC variability derives from genetic factors (2). CETP is a plasma glycoprotein that transfers cholesterol ester from HDLC to triglyceride (TG)-rich lipoproteins and regulates plasma HDLC levels $(3,4)$. Two CETP gene mutations, an intron $14 \mathrm{G}(+1)$-to-A mutation (I14A) and a missense mutation, Asp442 to Gly within exon 15 (D442G), first described in Japanese population, were found to be associated with a CETP deficiency and increased HDLC levels $(5,6)$. In addition, several common restriction fragment length polymorphisms (RFLPs) have also been reported in the CETP gene locus (7-9). The most studied RFLP to date has been TaqIB, which has been shown to be a silent base change

Received December 2004; accepted April 29, 2005.

Correspondence: Reiko Ohmori, Ph.D., First Department of Internal Medicine, National Defense Medical College, 3-2 Namiki, Tokorozawa, Saitama 359-8513, Japan: e-mail: rhirano@ndmc.ac.jp

DOI: 10.1203/01.pdr.0000183782.57705.fc
The frequency of the TaqIB2 allele was 0.34 , which was lower than that observed in other Asian populations. TaqIB2B2 carriers also had significantly higher HDLC levels, but this association was weaker than that of the D442G mutation. Overall, genetic variations at the CETP gene locus may account for a significant proportion of HDLC variation in Vietnamese children. (Pediatr Res 58: 1249-1253, 2005)
Abbreviations
CETP, cholesteryl ester transfer protein
HDLC, high-density lipoprotein cholesterol
TG, triglyceride

affecting the 277th nucleotide in the first intron of the gene. The B2 allele (in which the TaqIB restriction site is absent) at this polymorphic site has been associated with increased HDLC levels and decreased CETP activities and levels in normolipemic subjects, thus resembling a mild form of CETP deficiency $(10-12)$. The risk of coronary artery disease is inversely related to plasma HDLC levels. Therefore, identification of the underlying genetic basis of plasma HDLC levels is key to the understanding of atherosclerosis-related diseases, which are among the 10 leading mortality causes in Vietnam (13). The aim of this study was to determine the importance of genetic variants in the CETP gene to predict the HDLC levels for the Vietnamese children under different nutritional statuses.

\section{METHODS}

Study subjects. The study subjects included 348 schoolgirls, aged 7 to 9 y old, who were randomly selected from two schools in the center of Hochiminh city (an urban area) and three schools in the suburban areas in Hochiminh city (a rural area). All the subjects were Kinh, which is the major ethnic group in Vietnam. The characteristics of the children have been described in detail elsewhere (14). The research protocol was approved by the Research and Ethical Review Board of the Ho Chi Minh Child Nutrition Center. The 
informed consent to participate in the study was given by the parents of the subjects.

Anthropometric and dietary intake measurement. Anthropometric measurements including the weight, height, and left mid-arm circumference were examined. The body mass index was calculated from the baseline measurements of body weight and height $\left(\mathrm{kg} / \mathrm{m}^{2}\right)$. The body fat was measured using a bioelectric impedance method on a body fat analyzer (TBF-511, Tanita Co., Ltd., Tokyo, Japan).

The parents were interviewed regarding the dietary intake of their children for three consecutive days and nutritionists carried out these interviews. The dietary intake was calculated according to Vietnamese food composition table (15).

Laboratory analyses. Fasting blood samples were obtained in EDTAcoated Vacutainer tubes during clinical examinations for children. The samples were stored at $-80^{\circ} \mathrm{C}$ until analysis. The total cholesterol (TC), LDL cholesterol (LDLC), HDLC, and TG levels were determined by enzymatic methods (Determiner L, Kyowa Medex, Tokyo, Japan).

Genomic DNA was isolated from $2 \mathrm{~mL}$ of whole blood from the subjects using a commercially available kit (QIA Amp DNA Mini Kit; QIAGEN, Valencia, CA). The Invader assay was used to determine any mutations of CETP I14A, D442G, and TaqIB polymorphism, as previously described (16).

Statistical analyses. The $\chi^{2}$ test was used to examine any differences in the distribution of the CETP genotypic frequencies among rural and urban groups. The Hardy-Weinberg equilibrium of the CETP polymorphism was also assessed by the $\chi^{2}$ test. Continuous variables were expressed as the mean $\pm \mathrm{SD}$, and significant differences of the plasma lipids between the CETP genotypes were evaluated by analysis of variance (ANOVA) and the post hoc test (Scheffé test). Statistical procedures were performed using the StatView statistical program 5.0 (SAS Institute Inc., Cary, NC). A $p$ value of $<0.05$ was considered to be statistically significant.

\section{RESULTS}

Frequencies for the I14A and D442G mutations and the TaqIB polymorphism in CETP gene. As shown in Table 1, none of subjects carried the I14A mutation. In contrast, the D442G mutation was detected in 17 people (8.8\%) from the rural subgroup and in seven people $(4.5 \%)$ from the urban subgroup. The difference in the frequency between two groups was insignificant. Only the D442G heterozygous mutant was found in these Vietnamese children. On analyzing the TaqIB polymorphism, the frequencies for the $\mathrm{B} 1 \mathrm{~B} 1, \mathrm{~B} 1 \mathrm{~B} 2$, and $\mathrm{B} 2 \mathrm{~B} 2$ variants were $43.5 \%, 44.6 \%$, and $11.9 \%$ in rural group and $44.5 \%, 45.8 \%$, and $9.7 \%$ in urban group, respectively. The distribution of $\mathrm{D} 442 \mathrm{G}$ mutation and TaqIB polymorphism were in Hardy-Weinberg equilibrium.

Nutritional statuses and the CETP genotypes. The urban group had a higher quantity of energy and fat intake and better anthropometric parameters than the rural group (Tables 2 and 3 ). There was no difference in the profiles regarding the dietary intake and anthropometric factors among CETP D442G or TaqIB genotypes in the rural group. However, the quantity of fat intake in the D442G mutant carriers was significantly higher than that of the wild-type carriers $(p<0.05$, Table 2$)$, and the quantity of fat intake was also significantly higher in the B2B2 carriers than that in the B1B1 carriers $(p<0.05$, Table 3).

Associations between CETP gene D442G mutation and the plasma lipid and lipoprotein levels. The $\mathrm{D} 442 \mathrm{G}$ mutant carriers had significantly higher HDLC levels than nonmutant carriers, and the HDLC levels in the rural group were $1.14 \pm$ 0.3 and $0.96 \pm 0.2 \mathrm{mmol} / \mathrm{L}(p<0.005)$ for mutant and nonmutant carriers, respectively, while in the urban group they were $1.50 \pm 0.1$ and $1.25 \pm 0.3 \mathrm{mmol} / \mathrm{L}(p<0.05)$ for mutant and nonmutant carriers, respectively (Table 4).

Associations between the CETP gene TaqIB polymorphism and plasma lipid and lipoprotein levels. An elevated plasma HDLC level in B2 allele carriers was observed dosedependently in both groups (Table 5). B1B1 carriers had lower HDLC levels $(0.93 \pm 0.2 \mathrm{mmol} / \mathrm{L})$ than the $\mathrm{B} 1 \mathrm{~B} 2$ carriers $(1.00 \pm 0.2 \mathrm{mmol} / \mathrm{L})$ and $\mathrm{B} 2 \mathrm{~B} 2$ carriers $(1.07 \pm 0.3 \mathrm{mmol} / \mathrm{L})$ in the rural group $(p<0.05)$. Likewise, TaqIB2 carriers tended to have elevated HDLC levels in the urban group $(1.33 \pm 0.3$ in B2B2 carriers, $1.27 \pm 0.3$ in B1B2 carriers and $1.23 \pm 0.3$ $\mathrm{mmol} / \mathrm{L}$ in B1B1 carriers) $[p=$ not significant $(\mathrm{NS})]$.

The interaction of the D442G mutation and TaqIB polymorphism regarding the plasma HDLC levels. The genetic effects of D442G and TaqIB on the HDLC levels in both the urban and rural groups are shown in Table 6. The D442G mutant carriers had higher HDLC levels than the nonmutant carriers in all types of TaqIB polymorphism ( $p=\mathrm{NS})$. In wild-type D442G carriers, the HDLC levels tended to increase in the TaqIB B2 carriers in both groups $(0.93 \pm 0.2,0.98 \pm$ 0.2 , and $1.04 \pm 0.3 \mathrm{mmol} / \mathrm{L}$ in B1B1, B1B2, and B2B2 carriers in the rural group, respectively, and $1.22 \pm 0.3,1.26 \pm 0.3$ and $1.32 \pm 0.3 \mathrm{mmol} / \mathrm{L}$ in $\mathrm{B} 1 \mathrm{~B} 1, \mathrm{~B} 1 \mathrm{~B} 2$ and $\mathrm{B} 2 \mathrm{~B} 2$ carriers in the urban group, respectively). In the $\mathrm{D} 442 \mathrm{G}$ mutant carriers, this trend was observed in the rural group $(1.12 \pm 0.2$ and $1.25 \pm$ $0.4 \mathrm{mmol} / \mathrm{L}$ in B1B2 carriers and B2B2 carriers in rural group, respectively), but it was not clear in the urban group (1.38 and 1.73 in B1B1 carriers, $1.45 \pm 0.1$ in B1B2 carriers, and $1.57 \mathrm{mmol} / \mathrm{L}$ in $\mathrm{B} 2 \mathrm{~B} 2$ carriers).

Table 1. Frequencies of CETP TaqIB polymorphism and D442G mutation in Vietnamese children

\begin{tabular}{|c|c|c|c|c|c|c|}
\hline & CETP I14A & \multicolumn{2}{|c|}{ CETP D442G } & \multicolumn{3}{|c|}{ CETP TaqIB } \\
\hline \multicolumn{7}{|l|}{ Frequency $\%$ (no.) } \\
\hline Rural $(n=193)$ & 0 & $8.8(17)$ & $91.2(176)$ & $43.5(84)$ & $44.6(86)$ & $11.9(23)$ \\
\hline Urban $(n=155)$ & 0 & $4.5(7)$ & $95.5(148)$ & $44.5(69)$ & $45.8(71)$ & $9.7(15)$ \\
\hline Allele frequency I14A & & \multicolumn{2}{|c|}{ D442G mutant } & \multicolumn{2}{|c|}{ B1 allele } & B2 allele \\
\hline Urban & 0 & \multicolumn{2}{|c|}{0.023} & \multicolumn{2}{|c|}{0.67} & 0.33 \\
\hline
\end{tabular}


Table 2. Nutritional status of Vietnamese children according to CETP D $442 G$ genotypes

\begin{tabular}{lcc}
\hline & Mutant & Wild type \\
\hline Rural $(n=193)$ & 17 & 176 \\
Energy intake $(\mathrm{kcal})$ & $1390 \pm 307$ & $1255 \pm 310$ \\
Fat intake E $(\%)$ & $16.1 \pm 5.2$ & $15.5 \pm 5.7$ \\
Carbohydrate intake E $(\%)$ & $69.1 \pm 6.1$ & $70.1 \pm 6.5$ \\
Protein intake E $(\%)$ & $14.8 \pm 2.0$ & $14.4 \pm 2.1$ \\
Body mass index $\left(\mathrm{kg} / \mathrm{m}^{2}\right)$ & $13.9 \pm 1.5$ & $14.0 \pm 1.2$ \\
Body fat $(\%)$ & $10.2 \pm 3.4$ & $10.7 \pm 2.9$ \\
Left mid-arm circumference $(\mathrm{cm})$ & $16.0 \pm 1.3$ & $16.0 \pm 1.3$ \\
Urban $(n=155)$ & 7 & 148 \\
Energy intake $(\mathrm{kcal})$ & $1991 \pm 384$ & $1772 \pm 346$ \\
Fat intake E $(\%)$ & $25.8 \pm 5.1 *$ & $22.2 \pm 4.2$ \\
Carbohydrate intake E $(\%)$ & $56.2 \pm 3.9$ & $59.6 \pm 5.2$ \\
Protein intake E $(\%)$ & $15.8 \pm 2.3$ & $15.9 \pm 2.2$ \\
Body mass index $\left(\mathrm{kg} / \mathrm{m}^{2}\right)$ & $16.4 \pm 1.8$ & $15.8 \pm 2.4$ \\
Body fat $(\%)$ & $14.3 \pm 4.7$ & $15.2 \pm 6.0$ \\
Left mid-arm circumference $(\mathrm{cm})$ & $18.3 \pm 2.6$ & $18.0 \pm 2.3$ \\
\hline
\end{tabular}

Values are the mean $\pm \mathrm{SD}$. E $(\%)$ is the percentage of total energy intake.

$* p<0.05$ when compared to wild type.

Table 3. Nutritional status of Vietnamese children according to CETP TaqIB genotypes

\begin{tabular}{lccc}
\hline & B1B1 & B1B2 & B2B2 \\
\hline Rural $(n=193)$ & 84 & 86 & 23 \\
Energy intake $(\mathrm{kcal})$ & $1315 \pm 331$ & $1234 \pm 287$ & $1214 \pm 316$ \\
Fat intake E $(\%)$ & $15.2 \pm 5.3$ & $16.1 \pm 6.2$ & $15.0 \pm 4.5$ \\
Carbohydrate intake E $(\%)$ & $70.3 \pm 6.2$ & $69.4 \pm 6.9$ & $71.0 \pm 5.5$ \\
Protein intake E $(\%)$ & $14.5 \pm 2.1$ & $14.5 \pm 2.1$ & $14.0 \pm 2.1$ \\
Body mass index $\left(\mathrm{kg} / \mathrm{m}^{2}\right)$ & $14.1 \pm 1.2$ & $13.9 \pm 1.3$ & $13.6 \pm 0.9$ \\
Body fat $(\%)$ & $10.8 \pm 2.6$ & $10.7 \pm 3.4$ & $10.1 \pm 2.4$ \\
Left mid-arm circumference & $16.0 \pm 1.2$ & $16.0 \pm 1.4$ & $15.6 \pm 1.3$ \\
$\quad(\mathrm{~cm})$ & & & \\
Urban $(n=155)$ & 69 & 71 & 15 \\
Energy intake (kcal) & $1772 \pm 356$ & $1768 \pm 359$ & $1893 \pm 265$ \\
Fat intake E $(\%)$ & $22.1 \pm 3.9$ & $22.3 \pm 4.6$ & $24.5 \pm 4.5 *$ \\
Carbohydrate intake E $(\%)$ & $60.2 \pm 4.4$ & $59.2 \pm 5.8$ & $56.8 \pm 4.2^{*}$ \\
Protein intake E $(\%)$ & $16.0 \pm 2.5$ & $15.7 \pm 2.2$ & $16.0 \pm 1.4$ \\
Body mass index (kg/m $\left.{ }^{2}\right)$ & $15.7 \pm 2.4$ & $15.9 \pm 2.5$ & $16.2 \pm 1.8$ \\
Body fat $(\%)$ & $15.1 \pm 6.0$ & $15.0 \pm 6.2$ & $16.1 \pm 4.2$ \\
Left mid-arm circumference & $18.0 \pm 2.3$ & $17.9 \pm 2.6$ & $18.2 \pm 1.3$ \\
$\quad(\mathrm{~cm})$ & & & \\
\hline
\end{tabular}

Values are the mean \pm SD. E (\%) is the percentage of total energy intake. $* p<0.05$ when compared to B1B1 carriers.

\section{DISCUSSION}

This study proved that a significant proportion of the variation in plasma HDLC levels was associated with the CETP genotypes in Vietnamese children. The effects of the CETP gene, including a $\mathrm{D} 442 \mathrm{G}$ mutation and the TaqIB polymorphism on plasma HDLC levels were examined in girls ranging from 7 to 9 y of age with different nutritional statuses while minimizing confounding factors such as puberty, medicines, and smoking.

Plasma HDLC levels in the children with D442G heterozygote were significantly elevated by $20 \%$ in comparison to wild-type children in the rural and urban area. This result was compatible with the findings of other studies carried out using adults in Chinese (17), Taiwanese (18), Japanese (19), and Korean (20) populations. D442G mutant carriers were thus shown to have a lower CETP activity and mass resulting in
Table 4. Plasma levels of lipids and lipoproteins of Vietnamese children according to CETP D442G genotypes

\begin{tabular}{cccc}
\hline & \multicolumn{2}{c}{ D442G } & \\
\cline { 2 - 3 } & Mutant & Wild type & $p$ \\
\hline Total $(n=348)$ & 24 & 324 & \\
TC $(\mathrm{mmol} / \mathrm{L})$ & $3.89 \pm 0.7$ & $4.05 \pm 0.8$ & $\mathrm{NS}$ \\
LDLC $(\mathrm{mmol} / \mathrm{L})$ & $2.03 \pm 0.6$ & $2.34 \pm 0.6$ & $<0.05$ \\
HDLC $(\mathrm{mmol} / \mathrm{L})$ & $1.25 \pm 0.3$ & $1.09 \pm 0.3$ & $<0.05$ \\
TG $(\mathrm{mmol} / \mathrm{L})$ & $1.09 \pm 0.4$ & $1.22 \pm 0.7$ & NS \\
Rural $(n=193)$ & 17 & 176 & \\
TC $(\mathrm{mmol} / \mathrm{L})$ & $3.70 \pm 0.5$ & $3.69 \pm 0.6$ & $\mathrm{NS}$ \\
LDLC $(\mathrm{mmol} / \mathrm{L})$ & $1.94 \pm 0.5$ & $2.11 \pm 0.5$ & $\mathrm{NS}$ \\
HDLC $(\mathrm{mmol} / \mathrm{L})$ & $1.14 \pm 0.3$ & $0.96 \pm 0.2$ & $<0.005$ \\
TG $(\mathrm{mmol} / \mathrm{L})$ & $1.17 \pm 0.4$ & $1.19 \pm 0.5$ & $\mathrm{NS}$ \\
Urban $(n=155)$ & 7 & 148 & \\
TC $(\mathrm{mmol} / \mathrm{L})$ & $4.36 \pm 0.7$ & $4.48 \pm 0.7$ & $\mathrm{NS}$ \\
LDLC $(\mathrm{mmol} / \mathrm{L})$ & $2.26 \pm 0.7$ & $2.61 \pm 0.6$ & $\mathrm{NS}$ \\
HDLC $(\mathrm{mmol} / \mathrm{L})$ & $1.50 \pm 0.1$ & $1.25 \pm 0.3$ & $<0.05$ \\
TG $(\mathrm{mmol} / \mathrm{L})$ & $0.90 \pm 0.3$ & $1.26 \pm 0.8$ & $\mathrm{NS}$ \\
\hline
\end{tabular}

Values are the mean $\pm \mathrm{SD}$

Table 5. Plasma levels of lipids and lipoproteins of Vietnamese girls according to CETP TaqIB polymorphism

\begin{tabular}{cccc}
\hline & \multicolumn{3}{c}{ CETP TaqIB } \\
\cline { 2 - 4 } & B1B1 & B1B2 & B2B2 \\
\hline Total $(n=348)$ & 153 & 157 & 38 \\
TC $(\mathrm{mmol} / \mathrm{L})$ & $3.96 \pm 0.7$ & $4.09 \pm 0.9$ & $4.17 \pm 0.7$ \\
LDLC $(\mathrm{mmol} / \mathrm{L})$ & $2.27 \pm 0.7$ & $2.36 \pm 0.6$ & $2.36 \pm 0.4$ \\
HDLC $(\mathrm{mmol} / \mathrm{L})$ & $1.06 \pm 0.3$ & $1.12 \pm 0.3$ & $1.18 \pm 0.3^{*}$ \\
TG $(\mathrm{mmol} / \mathrm{L})$ & $1.28 \pm 0.7$ & $1.16 \pm 0.6$ & $1.17 \pm 0.4$ \\
Rural $(n=193)$ & 84 & 86 & 23 \\
TC $(\mathrm{mmol} / \mathrm{L})$ & $3.65 \pm 0.6$ & $3.69 \pm 0.7$ & $3.84 \pm 0.7$ \\
LDLC $(\mathrm{mmol} / \mathrm{L})$ & $2.08 \pm 0.4$ & $2.10 \pm 0.6$ & $2.14 \pm 0.5$ \\
HDLC $(\mathrm{mmol} / \mathrm{L})$ & $0.93 \pm 0.2$ & $1.00 \pm 0.2$ & $1.07 \pm 0.3 *$ \\
TG $(\mathrm{mmol} / \mathrm{L})$ & $1.23 \pm 0.5$ & $1.15 \pm 0.6$ & $1.22 \pm 0.5$ \\
Urban $(n=155)$ & 69 & 71 & 15 \\
TC $(\mathrm{mmol} / \mathrm{L})$ & $4.34 \pm 0.7$ & $4.57 \pm 0.8$ & $4.68 \pm 0.5$ \\
LDLC $(\mathrm{mmol} / \mathrm{L})$ & $2.48 \pm 0.6$ & $2.67 \pm 0.7$ & $2.71 \pm 0.5$ \\
HDLC $(\mathrm{mmol} / \mathrm{L})$ & $1.23 \pm 0.3$ & $1.27 \pm 0.3$ & $1.33 \pm 0.3$ \\
TG $(\mathrm{mmol} / \mathrm{L})$ & $1.34 \pm 0.9$ & $1.18 \pm 0.7$ & $1.09 \pm 0.4$ \\
\hline
\end{tabular}

Values are the mean $\pm \mathrm{SD}$

$* p<0.05$ when compared to B1B1 carriers.

higher HDLC levels due to a slower rate of apoA-I catabolism (21-23). In contrast, one study on Japanese children (average age of 10) showed that plasma levels of HDLC, apoA-I, and apoA-II did not increase in the D442G heterozygous carriers in comparison to wild-type carriers (24). The authors of this study concluded that the D442G mutation, by itself, might not affect HDLC metabolism in children (24). The discrepancy between this result and our result might be explained by their small sample size (only 32 boys and 33 girls of wild type and 10 boys and 11 girls of heterozygotes). The magnitude of the elevated plasma HDLC levels caused by the D442G mutation in the Vietnamese children with a low fat intake was similar to those of other populations with a higher fat intake $(25.2 \%)$ in the Japanese (25). Therefore, the effect of this mutation on plasma HDLC levels was not influenced by the low fat intake.

An effect of the TaqIB2 allele on plasma HDLC levels was also observed in Vietnamese children, regardless of the nutritional status, although the elevated effect of the TaqIB2 allele 
Table 6. The interaction between CETP TaqIB and D442G genotypes and HDLC levels in Vietnamese girls

\begin{tabular}{lccrr}
\hline & B1B1 & B1B2 & B2B2 & Total \\
\hline Rural $(n)$ & & & & \\
D442G Wild type & 84 & 73 & 19 & 176 \\
D442G Mutant & 0 & 13 & 4 & 17 \\
$\quad$ Total & 84 & 86 & 23 & 193 \\
Plasma HDLC levels & & & & \\
$\quad$ (mmol/L) & & & & \\
D442G Wild type & $0.93 \pm 0.2$ & $0.98 \pm 0.2$ & $1.04 \pm 0.3$ & \\
D442G Mutant & & $1.12 \pm 0.2$ & $1.25 \pm 0.4$ & \\
Urban $(n)$ & & & & \\
D442G Wild type & 67 & 67 & 14 & 148 \\
D442G Mutant & 2 & 4 & 1 & 7 \\
Total & 69 & 71 & 15 & 155 \\
Plasma HDLC levels & & & & \\
$\quad$ (mmol/L) & & & & \\
D442G Wild type & $1.22 \pm 0.3$ & $1.26 \pm 0.3$ & $1.32 \pm 0.3$ & \\
D442G Mutant & 1.38 and 1.73 & $1.45 \pm 0.1$ & 1.57 & \\
\hline
\end{tabular}

Values are the mean \pm SD.

The plasma HDLC levels in each genotype were not significantly different.

on HDLC levels was found to be weaker than that in the D442G mutation. In both groups of children in rural and urban settings, plasma HDLC levels in TaqIB2 allele carriers were higher than those in TaqIB1 allele carriers. In comparison to the B1 homozygote, plasma HDLC levels of the B2 homozygote increased by $15 \%$ and $8 \%$ in rural and urban children, respectively. In the present study, no data on the CETP protein level or activity were available; however, previous reports showed that the B2 allele as well as D442G mutant were both associated with a decrease in the CETP protein level or activity $(19,24,26)$. The site of the D442G mutation is close to the active site of CETP, and the cellular expression of mutant cDNA leads to a reduction in the CETP secretion and the specific activity (6). On the other hand, the mechanism by which the TaqIB polymorphism may affect the CETP protein level or activity is not well understood. It is plausible to explain that this polymorphism is in linkage disequilibrium with some unknown functional mutation in the CETP gene. In either genotype, the CETP protein level or activity was decreased, resulting in higher HDLC levels.

Other studies showed that the association between CETP genotypes and plasma HDLC levels was decreased due to environmental factors including smoking (27), obesity, and high TG levels (18) and was enhanced by alcohol consumption $(27,28)$. Therefore, the interaction between CETP genotypes and environmental factors on plasma HDLC levels might occur in individuals with high TG levels and/or obese people who are vulnerable to developing metabolic syndrome. However, such interaction might not be found in those with a low fat intake. Obese children have been reported to have increased serum CETP levels and lower plasma HDLC levels $(29,30)$. Only $2.3 \%$ of the children (eight children) in this study were overweight (classified as overweight if the weight-for-height $Z$ score was $>2$ ). These overweight children showed lower plasma HDLC levels than their counterparts (1.16 versus 1.26 $\mathrm{mmol} / \mathrm{L}$ ), but the change was not significantly different.

The frequency of the CETP D442G mutation in the Vietnamese was comparable to that in other Asian populations including Chinese (5\%) (17), Taiwanese (6.7\%) (18), Japanese (7.28\%) (19), and Korean (5.9\%) (20). This mutation was rarely found in Europeans (27), so it seems that this mutation is particular to Asian populations. The CETP TaqIB B2 allele frequency of the Vietnamese was lower than those of the Taiwanese (42.3\%) (18), Japanese (49.9\%) (26), and nearly the same as those of Koreans (36\%) (20). In whites, the frequency of the B2 allele was $44 \%$ (31), and therefore it was also higher than that in the Vietnamese. The CETP I14A mutation found neither in Vietnamese children, Taiwanese (18), nor Koreans (20), whereas it is $0.55 \%$ in the Japanese (19) and $1 \%$ in the Chinese (17). However, the frequency of the I14A mutation also varies in different regions in Japan, and this mutation was found to be 20 -fold more frequent in Omagari than in other areas (32).

In conclusion, our findings suggest that the roles of CETP D442G mutation and TaqIB polymorphism might explain a significant proportion of the variability in plasma HDLC levels in Vietnamese children. Furthermore, this is the first report to indicate the effects of a $\mathrm{D} 442 \mathrm{G}$ mutation and the TaqIB polymorphism on the plasma HDLC levels in subjects with a low fat intake. The effect of the D442G and TaqIB genotype on the plasma HDLC levels was not related to a low fat diet. Additional studies therefore need to be conducted to demonstrate whether these CETP genotypes play an important role in the risk of coronary artery disease among the Vietnamese population.

Acknowledgment. The technical assistance of M. Nagano during the genotype analyses is gratefully acknowledged.

\section{REFERENCES}

1. Tall AR 1990 Plasma high density lipoprotein. Metabolism and relationship to atherogenesis. J Clin Invest 86:379-384

2. Cohen JC, Wang Z, Grundy SM, Stoesz MR, Guerra R 1994 Variation at the hepatic lipase and apolipoprotein AI/CIII/AIV loci is a major cause of genetically determined variation in plasma HDL cholesterol levels. J Clin Invest 94:2377-2384

3. Barter PJ, Brewer HB Jr, Chapman MJ, Hennekens CH, Rader DJ, Tall AR 2003 Cholesteryl ester transfer protein: a novel target for raising HDL and inhibiting atherosclerosis. Arterioscler Thromb Vasc Biol 23:160-167

4. Boekholdt SM, Thompson JF 2003 Natural genetic variation as a tool in understanding the role of CETP in lipid levels and disease. J Lipid Res 44:1080-1093

5. Brown ML, Inazu A, Hesler CB, Agellon LB, Mann C, Whitlock ME, Marcel YL, Milne RW, Koizumi J, Mabuchi H, et al 1989 Molecular basis of lipid transfer protein deficiency in a family with increased high-density lipoproteins. Nature 342:448-451

6. Takahashi K, Jiang XC, Sakai N, Yamashita S, Hirano K, Bujo H, Yamazaki H, Kusunoki J, Miura T, Kussie P, et al 1993 A missense mutation in the cholesteryl ester transfer protein gene with possible dominant effects on plasma high density lipoproteins. J Clin Invest 92:2060-2064

7. Drayna D, Lawn R 1987 Multiple RFLPs at the human cholesteryl ester transfer protein (CETP) locus. Nucleic Acids Res 15:4698-

8. Freeman DJ, Griffin BA, Holmes AP, Lindsay GM, Gaffney D, Packard CJ, Shepherd J 1994 Regulation of plasma HDL cholesterol and subfraction distribution by genetic and environmental factors: associations between the TaqIBRFLP in the CETP gene and smoking and obesity. Arterioscler Thromb 14:336-344

9. Zuliani G, Hobbs HH 1990 EcoN I polymorphism in the human cholesteryl ester transfer protein (CETP) gene. Nucleic Acids Res 18:2834-

10. Gudnason V, Kakko S, Nicaud V, Savolainen MJ, Kesaniemi YA, Tahvanainen E, Humphries S 1999 Cholesteryl ester transfer protein gene effect on CETP activity and plasma high-density lipoprotein in European populations. The EARS Group. Eur J Clin Invest 29:116-128

11. Brousseau ME, O'Connor JJ Jr, Ordovas JM, Collins D, Otvos JD, Massov T, McNamara JR, Rubins HB, Robins SJ, Schaefer EJ 2002 Cholesteryl ester transfer protein TaqIB2B2 genotype is associated with higher HDL cholesterol levels and lower risk of coronary heart disease end points in men with HDL deficiency: Veterans Affairs HDL Cholesterol Intervention Trial. Arterioscler Thromb Vasc Biol 22:11481154

12. Ordovas JM, Cupples LA, Corella D, Otvos JD, Osgood D, Martinez A, Lahoz C, Coltell O, Wilson PW, Schaefer EJ 2000 Association of cholesteryl ester transfer 
protein-TaqIB polymorphism with variations in lipoprotein subclasses and coronary heart disease risk: the Framingham study. Arterioscler Thromb Vasc Biol 20:13231329

13. Ministry of Health 2000 Medical Statistics of Vietnam. Medical Publisher, Hanoi, pp 136.

14. Tuyet Mai T, Kim Hung N, Kawakami M, Nguyen VC 2003 Macronutrient intake and nutritional status of primary school-aged girls in rural and urban areas of South Vietnam. J Nutr Sci Vitaminol 49:13-20

15. Giay T, Khoi HH, Duc BM 2000 Nutritive Composition Table of Vietnamese Foods Medical Publisher, Hanoi, pp 23-105.

16. Nagano M, Yamashita S, Hirano K, Ito M, Maruyama T, Ishihara M, Sagehashi Y, Oka T, Kujiraoka T, Hattori H, Nakajima N, Egashira T, Kondo M, Sakai N, Matsuzawa Y 2002 Two novel missense mutations in the CETP gene in Japanese hyperalphalipoproteinemic subjects: high-throughput assay by Invader assay. J Lipid Res 43:1011-1018

17. Zhuang Y, Wang J, Qiang H, Li Y, Liu X, Li L, Chen G 2002 Cholesteryl ester transfer protein levels and gene deficiency in Chinese patients with cardiocerebrovascular diseases. Chin Med J 115:371-374

18. Hsu LA, Ko YL, Hsu KH, Ko YH, Lee YS 2002 Genetic variations in the cholestery ester transfer protein gene and high density lipoprotein cholesterol levels in Taiwanese Chinese. Hum Genet 110:57-63

19. Inazu A, Jiang XC, Haraki T, Yagi K, Kamon N, Koizumi J, Mabuchi H, Takeda R, Takata K, Moriyama Y, Doi M, Tall A 1994 Genetic cholesteryl ester transfer protein deficiency caused by two prevalent mutations as a major determinant of increased levels of high density lipoprotein cholesterol. J Clin Invest 94:1872-1882

20. Hong SH, Kim YR, Song J, Kim JQ 2001 Genetic variations of cholesterol ester transfer protein gene in Koreans. Hum Biol 73:815-821

21. Ikewaki K, Rader DJ, Sakamoto T, Nishiwaki M, Wakimoto N, Schaefer JR, Ishikawa T, Fairwell T, Zech LA, Nakamura H, et al 1993 Delayed catabolism of high density lipoprotein apolipoproteins A-I and A-II in human cholesteryl ester transfer protein deficiency. J Clin Invest 92:1650-1658

22. Kondo I, Berg K, Drayna D, Lawn R 1989 DNA polymorphism at the locus for human cholesteryl ester transfer protein (CETP) is associated with high density lipoprotein cholesterol and apolipoprotein levels. Clin Genet 35:49-56
23. Akita H, Chiba H, Tsuchihashi K, Tsuji M, Kumagai M, Matsuno K, Kobayashi K 1994 Cholesteryl ester transfer protein gene: two common mutations and their effect on plasma high-density lipoprotein cholesterol content. J Clin Endocrinol Metab 79:1615-1618

24. Arashiro R, Katsuren K, Maung KK, Fukuyama S, Ohta T 2001 Effect of a common mutation (D442G) of the cholesteryl ester transfer protein gene on lipids and lipoproteins in children. Pediatr Res 50:455-459

25. Ministry of Health, Labor and Welfare 2001 The National Nutrition Survey in Japan. Daiichi Publisher, Tokyo, pp 32-33.

26. Ikewaki K, Mabuchi H, Teramoto T, Yamada N, Oikawa S, Sasaki J, Takata K, Saito Japan CETP Study Group 2003 Association of cholesteryl ester transfer protein activity and TaqIB polymorphism with lipoprotein variations in Japanese subjects. Metabolism 52:1564-1570.

27. Hannuksela ML, Liinamaa MJ, Kesaniemi YA, Savolainen MJ 1994 Relation of polymorphisms in the cholesteryl ester transfer protein gene to transfer protein activity and plasma lipoprotein levels in alcohol drinkers. Atherosclerosis 110:35-44

28. Fumeron F, Betoulle D, Luc G, Behague I, Ricard S, Poirier O, Jemaa R, Evans A, Arveiler D, Marques-Vidal P, et al 1995 Alcohol intake modulates the effect of a polymorphism of the cholesteryl ester transfer protein gene on plasma high density lipoprotein and the risk of myocardial infarction. J Clin Invest 96:1664-1671

29. Asayama K, Hayashibe H, Dobashi K, Uchida N, Nakane T, Kodera K, Shirahata A 2002 Increased serum cholesteryl ester transfer protein in obese children. Obes Res 10:439-446

30. Hayashibe H, Asayama K, Nakane T, Uchida N, Kawada Y, Nakazawa S 1997 Increased plasma cholesteryl ester transfer activity in obese children. Atherosclerosis 129:53-58

31. Dachet C, Poirier O, Cambien F, Chapman J, Rouis M 2000 New functional promoter polymorphism, CETP/-629, in cholesteryl ester transfer protein (CETP) gene related to CETP mass and high density lipoprotein cholesterol levels: role of the Sp1/Sp3 in transcriptional regulation. Arterioscler Thromb Vasc Biol 20:507-515

32. Hirano K, Yamashita S, Nakajima N, Arai T, Maruyama T, Yoshida Y, Ishigami M, Sakai N, Kameda-Takemura K, Matsuzawa Y 1997 Genetic cholesteryl ester transfe protein deficiency is extremely frequent in the Omagari area of Japan: marked hyperalphalipoproteinemia caused by CETP gene mutation is not associated with longevity. Arterioscler Thromb Vasc Biol 17:1053-1059 